\title{
The Effect of Sodium Nitrite on Induction of Apoptosis in Human Gastric Adenocarcinoma Epithelia (AGS) Cells
}

\author{
Yanchao Liu1 ${ }^{*}$, Qiliang Qin ${ }^{2 *}$, Agula Bo ${ }^{1 *}$, Hairong Zhang1, Qing Zhang33, Wenli Hao1, \\ Yueling Hu${ }^{1}$, Juan Sun${ }^{1 \#}$ \\ ${ }^{1}$ Inner Mongolia Medical University, Hohhot, China \\ ${ }^{2}$ Food and Drug Inspection Testing Center, Huangnan Tibetan Autonomous Prefecture, Qinghai Province, China \\ ${ }^{3}$ Inner Mongolia Medical University Affiliated Hospital, Hohhot, China \\ Email: "cnsunjuan@aliyun.com
}

Received 23 September 2015; accepted 13 November 2015; published 16 November 2015

Copyright (C) 2015 by authors and Scientific Research Publishing Inc.

This work is licensed under the Creative Commons Attribution International License (CC BY). http://creativecommons.org/licenses/by/4.0/

(c) (i) Open Access

\section{Abstract}

To examine the cytocidal effect of sodium nitrite on the cancer cell, we subjected human gastric adenocarcinoma epithelia (AGS) cells to various experimentation following exposure to sodium nitrite, and measured the resulting changes in the levels of cell death, lactate dehydrogenase (LDH) release, and caspase- $3,-6,-8$, and -9 activities. Our data revealed that, in AGS cells, treatment with $\geq 6.25 \mathrm{mM}$ sodium nitrite for $8 \mathrm{~h}$ resulted in an obvious increase in cell death. LDH release was also markedly increased following sodium nitrite treatment, but at a concentration of $\geq 6.25 \mathrm{mM}$ for 24 $h$. This increasing trend showed a positive correlation $(r=0.9564, P<0.05)$. In addition, we detected pronounced increases in caspase activities with various concentrations of sodium nitrite: caspase- 3 at $\geq 25 \mathrm{mM}$ for $1 \mathrm{~h}, \geq 12.5 \mathrm{mM}$ for $3 \mathrm{~h}$ and $6 \mathrm{~h}$; caspase- 9 at $50 \mathrm{mM}$ for $1 \mathrm{~h}$ and $3 \mathrm{~h}$, and $\geq 6.25 \mathrm{mM}$ for $6 \mathrm{~h}$; and caspase- 6 at $50 \mathrm{mM}$ for $1 \mathrm{~h}$ and $3 \mathrm{~h}$. We did not however, detect any observable increase in the activity of caspase- 8 following sodium nitrite treatment at any concentration or for any duration of treatment in this study. This data demonstrates that, in AGS cells, higher concentrations or longer durations of treatment with sodium nitrite could exhibit a cytocidal effect, and that sodium nitrite could induce apoptosis via activation of the caspase-9, caspase-3 cascade (intrinsic pathway) and caspase- 6 .

\section{Keywords}

Sodium Nitrite, Human Gastric Adenocarcinoma Epithelia (AGS) Cells, Apoptosis

\footnotetext{
"Yanchao Liu, Qiliang Qin and Agula Bo contributed equally to this work.

${ }^{\#}$ Corresponding author.
}

How to cite this paper: Liu, Y.C., Qin, Q.L., Bo, A., Zhang, H.R., Zhang, Q., Hao, W.L., Hu, Y.L. and Sun, J. (2015) The Effect of Sodium Nitrite on Induction of Apoptosis in Human Gastric Adenocarcinoma Epithelia (AGS) Cells. Pharmacology \& Pharmacy, 6, 496-501. http://dx.doi.org/10.4236/pp.2015.611052 


\section{Introduction}

The use of sodium nitrite $\left(\mathrm{NaNO}_{2}\right)$ can be dated back as early as 850 B.C., when it was employed in the meat curing process [1]. It was also used to impart flavor and color to preserved meat [2], and thus had been widely used as a food additive [3]. In the early 20th century, it was suggested that nitrite might increase the incidence of cancer, and the toxic nature of high nitrite levels had since been confirmed [4] [5]. However, nitrites are also used in the medicinal field [6] and sodium nitrite may have therapeutic potential as a nitric oxide (NO) prodrug in the treatment of tumors, allowing a transient increase in the delivery and efficacy of anti-cancer drugs [1]. To better understand the mechanism under which nitrite-mediated therapy affects tumor progression and development, direct investigation of the effect of sodium nitrite on carcinogenesis, both in vitro and in vivo, is paramount.

Gastric cancers are malignancies of the stomach, as known as stomach cancer. And the adenocarcinoma is a common type cancer in the stomach. The mechanism of gastric carcinogenesis remains equivocal [7]. Genetic and environmental factors may play a role in the etiology of this disease [8] [9]. Gastric cancer is currently the third leading cause of cancer death worldwide, it used to be the second cause after lung cancer and remains a major public health problem in the world [10]-[12]. Although the incidence of gastric cancer has decreased around the world over the last 3 decades, which still show a higher mortality than other countries in East Asian countries [11]. Cure is possible for patients presenting with early stage disease [10]. However, because early gastric cancer produces few symptoms, most gastric cancer patients are diagnosed in advanced-stage or metastatic disease with a poor prognosis [10]. Radiographic screening and endoscopic screening are common technologies to detect early-stage gastric cancer [11].

The main treatment option is the gastrectomy combined with chemotherapy and radiation therapy protocols. Some drugs that inhibit the vascular endothelial growth pathway are also used to treatment, including bevacizumab, sunitinib, sorafenib, apatinib, regorafenib, and ramucirumab, etc. [10]. In addition, micromolecule compounds with inducing cancer cell apoptosis features (e.g. sodium citrate) are extensive researched as another anticancer way [13].

Our previous study demonstrated that high concentrations of sodium nitrite could exhibit cytotoxic activity in human gastric adenocarcinoma epithelia (AGS) cells via an induction of inflammatory cytokines and a decrease in cell proliferation [7]. Additionally, recent research suggests that sodium nitrite could induce apoptosis in rat cardiac tissue [8]. In our current study, we examine the apoptotic effect induced by sodium nitrite in AGS cells.

\section{Materials and Methods}

\subsection{Chemical Agents and Cells}

The human AGS cell line was obtained from Dainippon Pharmaceutical Co., Ltd., Osaka, Japan. Cells were cultivated in HAM F12 (Gibco) nutrient mixture with L-glutamine (Gibco-Invitrogen, Carlsbad, CA, USA) supplemented with penicillin (100 IU/mL, Gibco), streptomycin (100 lg/mL, Gibco), and 10\% fetal bovine serum (FBS, Gibco). Sodium nitrite was used as an inducing agent, which was obtained from Wako Pure Chemical Industries, Japan.

\subsection{Cell Death Detection}

AGS cells were seeded in 96-well plates (Corning Costar Corp., Corning, NY, USA) at $1 \times 10^{4}$ cells/100 $\mu 1 /$ well and incubated for $3 \mathrm{~h}$ at $37^{\circ} \mathrm{C}$ with $5 \% \mathrm{CO}_{2}$. The AGS cells were then grown in the presence of sodium nitrite at concentrations of $3.125,6.25,12.5,25$, and $50 \mathrm{mM}$, for $1 \mathrm{~h}, 4 \mathrm{~h}$ or $8 \mathrm{~h}$. At the conclusion of each treatment period, the cells were then centrifuged, and cell death was detected using the Cell Death Detection ELISAPLUS kit (Biovision, USA). The histone-complexed DNA fragments were detected directly in the culture supernatant with measurement of absorbance at $405 \mathrm{~nm}$ using an ELISA plate reader (Ceres UV $900 \mathrm{H}$ D; Biotek Instruments, Winooski, VT).

\subsection{Lactate Dehydrogenase (LDH) Release Assay}

To measure cytotoxicity, LDH release was detected after AGS cells underwent pre-treatment with 3.125, 6.25, 12.5, 25, or $50 \mathrm{mM}$ sodium nitrite for $4 \mathrm{~h}, 8 \mathrm{~h}$, or $24 \mathrm{~h}$. Cell supernatants were collected and the LDH-Cytotoxicity Assay Kit (Biovision, USA) was used to measure the amount of LDH present by quantifying the formazan dye 
by spectrophotometry at a wavelength of $492 \mathrm{~nm}$. Triton X-100 (1\%) was used as a positive control.

\subsection{Caspase Activity Assay}

The activities of caspase-3, -6 , -8, and -9 were determined using Apo Target ${ }^{\mathrm{TM}}$ Caspase colorimetric kits (Biosource, USA). AGS cells were treated with $0,1.25,2.5,5.0,10.0$, or $20.0 \mathrm{mM}$ sodium nitrite for $1 \mathrm{~h}, 3 \mathrm{~h}$, or $6 \mathrm{~h}$. Assays were performed in 96-well plates, and the reaction mixtures were incubated at $37^{\circ} \mathrm{C}$ for $4 \mathrm{~h}$ or overnight before measurement of absorbance at $405 \mathrm{~nm}$ using an ELISA plate reader (Ceres UV $900 \mathrm{H}$ D; Biotek Instruments, Winooski, VT).

\subsection{Statistical Analysis}

Data from three parallel experiments was expressed as the mean \pm standard deviation (SD). The correlation coefficient ( $\mathrm{r}$ ) was calculated for $\mathrm{LDH}$ release, with $\mathrm{P}<0.05$ conferring statistical significance.

\section{Results}

\subsection{Cell Death Detection}

After treating the AGS cells with different concentrations of sodium nitrite for $1 \mathrm{~h} \mathrm{or} 4 \mathrm{~h}$, the resulting data indicated that the increasing trend of cell death was not distinct following increasing treatment concentration. However, when the treatment time was extended to $8 \mathrm{~h}$, cell death increased noticeably at treatment concentrations greater than $6.25 \mathrm{mM}$. The increasing trend in cell death exhibited a dose-dependence at concentrations between $6.25 \mathrm{mM}$ and $25 \mathrm{mM}$ (Figure 1).

\subsection{Lactate Dehydrogenase (LDH) Release Assay}

LDH release from AGS cells was relatively stable after treatment for $4 \mathrm{~h}$ or $8 \mathrm{~h}$ with 3.125 to $50 \mathrm{mM}$ sodium nitrite. However, when treatment time was increased to $24 \mathrm{~h}$, LDH release increased at concentrations from 3.125 to $50 \mathrm{mM}$, with this increasing trend showing a positive correlation $(\mathrm{r}=0.9564, \mathrm{P}<0.05)$ (Figure 2).

\subsection{Caspase Activity Assay}

Caspase-3 activity increased following treatment with $\geq 25 \mathrm{mM}$ sodium nitrite for $1 \mathrm{~h}$, and $\geq 12.5 \mathrm{mM}$ for $3 \mathrm{~h}$ or $6 \mathrm{~h}$, as compared to the control. In addition, activity of caspase-9 increased after treatment with $50 \mathrm{mM}$ sodium nitrite for $1 \mathrm{~h}$ or $3 \mathrm{~h}$, and $\geq 6.25 \mathrm{mM}$ for $6 \mathrm{~h}$, when compared to the control. Moreover, activity of caspase- 6 increased after treatment with $50 \mathrm{mM}$ sodium nitrite for $1 \mathrm{~h}$, and $\geq 12.5 \mathrm{mM}$ for $3 \mathrm{~h}$, when compared to the control. Contrastingly, caspase-8 activity did not change distinctly following the increase in treatment time or concentration, when compared to the control (Figure 3).

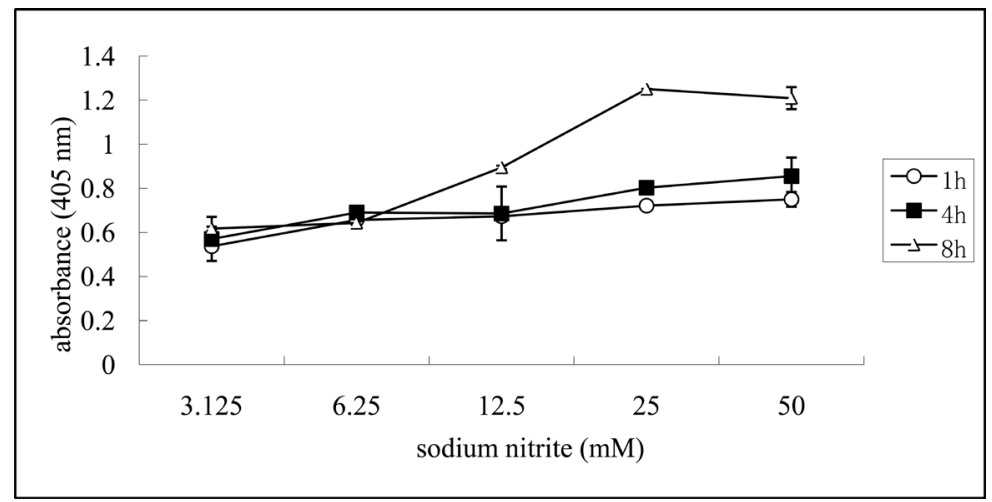

Figure 1. Cell death in AGS cells following treatment with different concentrations of $\mathrm{NaNO}_{2}$ for different periods of time. There was almost no change in cell death after $1 \mathrm{~h}$ and $4 \mathrm{~h}$ of treatment, however, after $8 \mathrm{~h}$ of treatment and with treatment concentrations over $6.25 \mathrm{mM}$, cell death increased obviously, exhibiting a dose-dependence between $6.25 \mathrm{mM}$ and $25 \mathrm{mM}$. Data represent mean values of determinations \pm SD. 


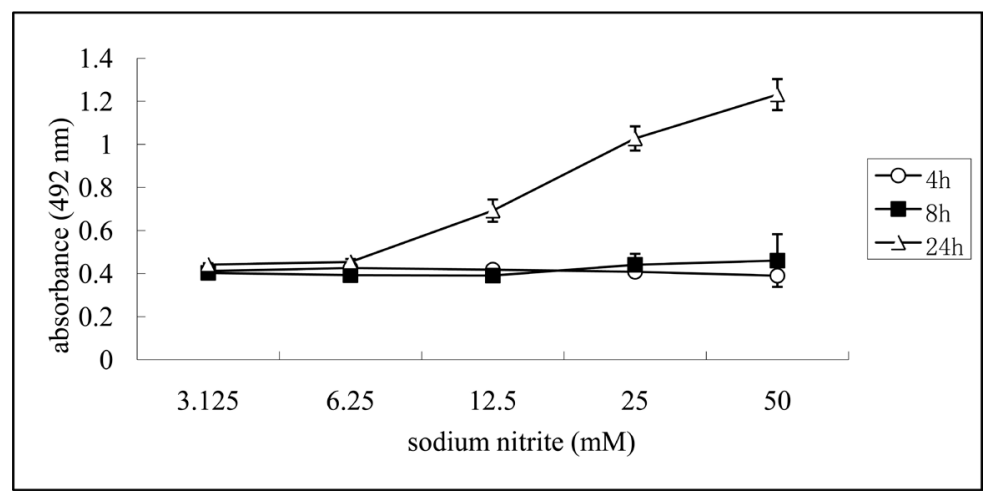

Figure 2. LDH release assay. AGS cells were treated with different concentrations $\mathrm{NaNO}_{2}$ for different durations of time. After $24 \mathrm{~h}$ of treatment, LDH release increased along with increasing treatment concentrations, and this increasing trend showed a positive correlation $(r=0.9564, \mathrm{P}<0.05)$. Although, when AGS cells were treated for the shorter duration of $4 \mathrm{~h}$ or $8 \mathrm{~h}$ with 3.125 to $50 \mathrm{mM} \mathrm{NaNO}_{2}$, $\mathrm{LDH}$ release was close to stable. Data represent mean values of determinations \pm SD.


Figure 3. Caspase activities assay. The activity of caspase- 3 increased after treatment with $\geq 25 \mathrm{mM} \mathrm{NaNO}_{2}$ for $1 \mathrm{~h}$, and $\geq 12.5 \mathrm{mM}$ for $3 \mathrm{~h}$ or $6 \mathrm{~h}$, as compared to the control (a); Caspase-9 activity was also increased after treatment with $50 \mathrm{mM}$ $\mathrm{NaNO}_{2}$ for $1 \mathrm{~h}$ or $3 \mathrm{~h}$, and $\geq 16.25 \mathrm{mM}$ for $6 \mathrm{~h}$, as compared to the control (d); Activity of caspase- 6 was increased after treatment with $50 \mathrm{mM} \mathrm{NaNO}_{2}$ for $1 \mathrm{~h}$, and $\geq 12.5 \mathrm{mM} \mathrm{NaNO}_{2}$ for $3 \mathrm{~h}$, as compared to the control (b); However, any observable increase in the activity of caspase- 8 following sodium nitrite treatment at any concentration or for any duration of treatment was not detected, as compared to the control (c). Data represent mean values of determinations \pm SD.

\section{Discussion}

Research surrounding sodium nitrite is plentiful due to both its usefulness and carcinogenesis. Despite this, the effect of sodium nitrite exposure on cancer cells remains equivocal [1] [14], in part because sodium nitrite can change the level of some inflammatory cytokines in cancer cells, as reported in our prior research [15]. Furthermore, sodium nitrite can, not only change the level of some inflammatory cytokines, but also induce apoptosis in cardiac tissue in rats, via extrinsic and intrinsic cell death pathways [16]. Although sodium nitrite can assist proliferation of cancer cells at low concentrations, high concentrations can induce the apoptotic program in 
cancer cells, as was previously reported in human hepatocarcinoma cells [17]. Our current research suggests that high concentrations or long treatment times with sodium nitrite can also induce the apoptotic program of AGS cells, providing further evidence to support the relationship between sodium nitrite exposure and cancer cells.

Caspases perform as initiators or executors in cell death programming; caspase-8 is an initiator of the extrinsic pathway, caspase-9 is an initiator of the intrinsic pathway, and caspases-3 and -6 are executors [18]. In this study, the activities of caspase-3, $-6,-8$, and -9 were detected. Our data revealed increased activities of caspase-3 and -9 , which is indicates that activation of the caspase9-caspase3 cascade was induced [19]. Contrastingly, caspase-8 activity remained unchanged in our experimentation, indicating that sodium nitrite-induced apoptosis in AGS cells acts via the intrinsic pathway, rather than the extrinsic pathway [20]. Additionally, because caspase- 6 activity was increased at $50 \mathrm{mM}$ sodium nitrite for $1 \mathrm{~h}$ and $3 \mathrm{~h}$, we can infer that caspase- 6 may only play a role in early stage apoptosis with higher treatment concentration. Although we don't know the sodium nitrite has an influence in the growth of normal gastric epithelia cells or not, the results of the experiments provide an evidence to understand the relationship between sodium nitrite and gastric cancer cells, or a reference to find a new way to treat the gastric cancer.

\section{Conclusion}

In this study, in AGS cells, higher concentrations or longer durations of treatment with sodium nitrite could exhibit a cytocidal effect. The cytocidal effect was reflected in inducing increased cell death, increased LDH release and the apoptosis of AGS cells. Cell death increased noticeably at $8 \mathrm{~h}$ with $>6.25 \mathrm{mM}$ sodium nitrite. LDH release increased at concentrations at $24 \mathrm{~h}$ with from 3.125 to $50 \mathrm{mM}$ sodium nitrite. When the sodium nitrite treatment was $50 \mathrm{mM}$ for $1 \mathrm{~h}$ or $3 \mathrm{~h}$, and $\geq 6.25 \mathrm{mM}$ for $6 \mathrm{~h}$, apoptosis could be induced via activation of the caspase-9, caspase-3 cascade (intrinsic pathway) and caspase-6, rather than the extrinsic pathway.

\section{References}

[1] Kevil, C.G., Kolluru, G.K., Pattillo, C.B. and Giordano, T. (2011) Inorganic Nitrite Therapy: Historical Perspective and Future Directions. Free Radical Biology and Medicine, 51, 576-593. http://dx.doi.org/10.1016/j.freeradbiomed.2011.04.042

[2] Pierson, M.D. and Smoot, L.A. (1982) Nitrite, Nitrite Alternatives, and the Control of Clostridium botulinum in Cured Meats. Critical Reviews in Food Science and Nutrition, 17, 141-187. http://dx.doi.org/10.1080/10408398209527346

[3] National Toxicology Program (2001) NTP Toxicology and Carcinogenesis Studies of SODIUM NITRITE (CAS NO. 7632-00-0) Drinking Water Studies in F344/N Rats and B6C3F1 Mice. National Toxicology Program Technical Report Series, 495, 1-274.

[4] Ringer, S. and Murrell, W. (1883) Nitrite of Sodium as a Toxic Agent. The Lancet, 2, 766-767. http://dx.doi.org/10.1016/S0140-6736(02)23900-8

[5] Magee, P.N. and Barnes, J.M. (1956) The Production of Malignant Primary Hepatic Tumours in the Rat by Feeding Dimethyl Nitrosamine. British Journal of Cancer, 10, 114-122. http://dx.doi.org/10.1038/bjc.1956.15

[6] Butler, A.R. and Feelisch, M. (2008) Therapeutic Uses of Inorganic Nitrite and Nitrate: From the Past to the Future. Circulation, 117, 2151-2159. http://dx.doi.org/10.1161/CIRCULATIONAHA.107.753814

[7] Peng, Q.S. and Xu, Y. (2015) Association between Promoter Polymorphisms of Matrix Metalloproteinase-1 and Risk of Gastric Cancer. Onco Targets and Terapy, 8, 2519-2526.

[8] Reeves, G.K., Pirie, K., Green, J., Bull, D. and Beral, V. (2012) Million Women Study Collaborators. Comparison of the Effects of Genetic and Environmental Risk Factors on in Situ and Invasive Ductal Breast Cancer. International Journal of Cancer, 131, 930-937. http://dx.doi.org/10.1002/ijc.26460

[9] Wang, X.Q., Terry, P.D. and Yan, H. (2009) Review of Salt Consumption and Stomach Cancer Risk: Epidemiological and Biological Evidence. World Journal of Gastroenterology, 15, 2204-2213. http://dx.doi.org/10.3748/wjg.15.2204

[10] Chan, M.M., Sjoquist, K.M. and Zalcberg, J.R. (2015) Clinical Utility of Ramucirumab in Advanced Gastric Cancer. Biologics, 22, 93-105.

[11] Hamashima, C. (2014) Current Issues and Future Perspectives of Gastric Cancer Screening. World Journal of Gastroenterology, 20, 13767-13774. http://dx.doi.org/10.3748/wjg.v20.i38.13767

[12] Ferlay, J., Shin, H.R., Bray, F., Forman, D., Mathers, C. and Parkin, D.M. (2010) Estimates of Worldwide Burden of Cancer in 2008: GLOBOCAN 2008. International Journal of Cancer, 127, 2893-2917.

http://dx.doi.org/10.1002/ijc.25516 
[13] Zhang, X., Varin, E., Allouche, S., Lu, Y., Poulain, L. and Icard, P. (2009) Effect of Citrate on Malignant Pleural Mesothelioma Cells: A Synergistic Effect with Cisplatin. Anticancer Research, 29, 1249-1254.

[14] Hord, N.G., Tang, Y. and Bryan, N.S. (2009) Food Sources of Nitrates and Nitrites: The Physiologic Context for Potential Health Benefits. The American Journal of Clinical Nutrition, 90, 1-10. http://dx.doi.org/10.3945/ajcn.2008.27131

[15] Sun, J., Aoki, K., Wang, W., Guo, A. and Misumi, J. (2006) Sodium Nitrite-Induced Cytotoxicity in Cultured Human Gastric Epithelial Cells. Toxicology in Vitro, 26, 1133-1138. http://dx.doi.org/10.1016/j.tiv.2006.02.005

[16] Al-Gayyar, M.M., Al Youssef, A., Sherif, I.O., Shams, M.E. and Abbas, A. (2014) Protective Effects of Arjunolic Acid against Cardiac Toxicity Induced by Oral Sodium Nitrite: Effects on Cytokine Balance and Apoptosis. Life Sciences, 111, 18-26. http://dx.doi.org/10.1016/j.lfs.2014.07.002

[17] Zhang, F.-L., Li, Y.-Q., Shi, Q., Li, Y.-H. and Huangfu, C.-S. (2011) Effects of Sodium Nitrite on Proliferation and Apoptosis on Human Hepatocarcinoma Cells. Chinese Pharmacological Bulletin, 27, 191-195.

[18] Riedl, S.J. and Shi, Y. (2004) Molecular Mechanisms of Caspase Regulation during Apoptosis. Nature Reviews Molecular Cell Biology, 5, 897-907. http://dx.doi.org/10.1038/nrm1496

[19] Kim, G.Y., Park, S.Y., Jo, A., Kim, M., Leem, S.H., Jun, W.J., Shim, S.I., Lee, S.C. and Chung, J.W. (2015) Gecko Proteins Induce the Apoptosis of Bladder Cancer 5637 Cell by Inhibiting Akt and Activating Intrinsic Caspase Cascade. BMB Reports.

[20] Creagh, E.M. (2014) Caspase Crosstalk: Integration of Apoptotic and Innate Immune Signaling Pathways. Trends in Immunology, 35, 631-640. http://dx.doi.org/10.1016/j.it.2014.10.004

\section{Abbreviations}

AGS: human gastric adenocarcinoma epithelia cell line; $\mathrm{LDH}$ : lactate dehydrogenase; $\mathrm{NaNO}_{2}$ : sodium nitrite; NO: nitric oxide; SD: standard deviation. 